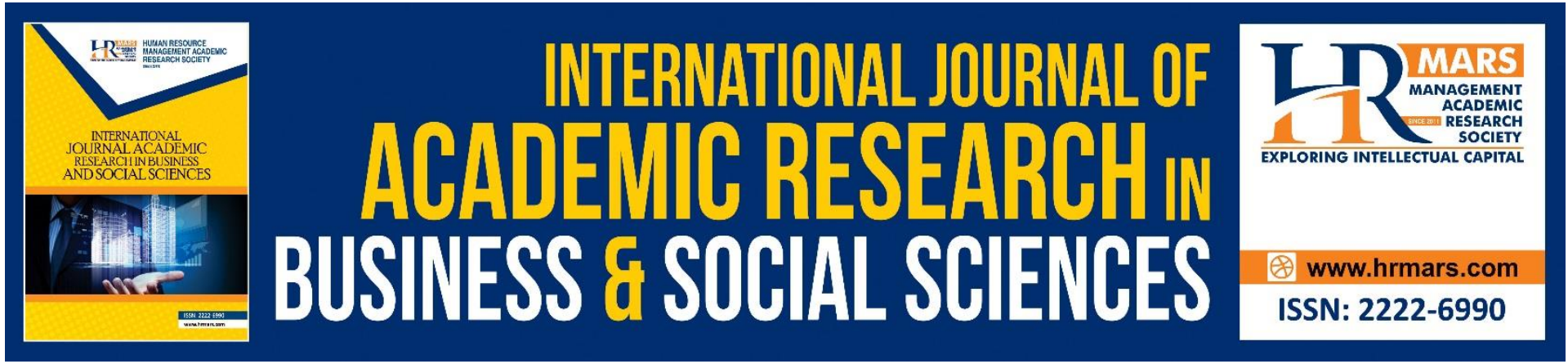

\title{
The Impact of Receipt in The Prophetic Period on Preserving the Noble Qur'an From Distortion
}

Ammar Kamal Ibrahim Othman, Mohamed Fathy Mohamed Abdelgelil, Ahmad Fauzi Hassan, Nur Sakiinah Ab Aziz

To Link this Article: http://dx.doi.org/10.6007/IJARBSS/v11-i9/11121

DOI:10.6007/IJARBSS/v11-i9/11121

Received: 01 July 2021, Revised: 30 July 2021, Accepted: 20 August 2021

Published Online: 16 September 2021

In-Text Citation: (Othman et al., 2021)

To Cite this Article: Othman, A. K. I., Abdelgelil, M. F. M., Hassan, A. F., \& Aziz, N. S. A. (2021). The Impact of Receipt in The Prophetic Period on Preserving the Noble Qur'an From Distortion. International Journal of Academic Research in Business and Social Sciences, 11(9), 1238-1247.

Copyright: @ 2021 The Author(s)

Published by Human Resource Management Academic Research Society (www.hrmars.com)

This article is published under the Creative Commons Attribution (CC BY 4.0) license. Anyone may reproduce, distribute, translate and create derivative works of this article (for both commercial and non-commercial purposes), subject to full attribution to the original publication and authors. The full terms of this license may be seen at: http://creativecommons.org/licences/by/4.0/legalcode

Vol. 11, No. 9, 2021, Pg. 1238 - 1247

Full Terms \& Conditions of access and use can be found at http://hrmars.com/index.php/pages/detail/publication-ethics 


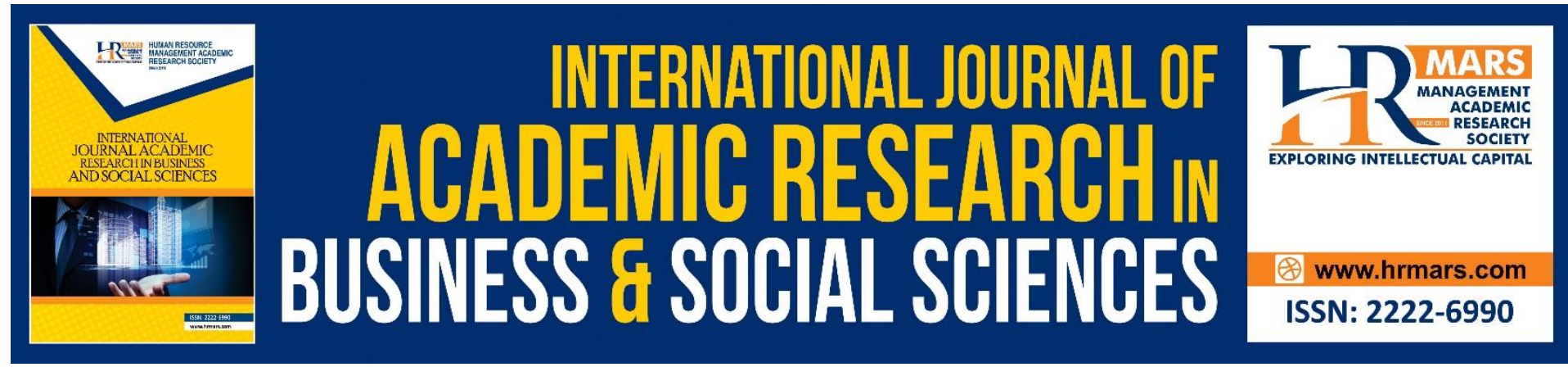

\title{
The Impact of Receipt in The Prophetic Period on Preserving the Noble Qur'an From Distortion
}

\author{
Ammar Kamal Ibrahim Othman, Mohamed Fathy Mohamed \\ Abdelgelil, Ahmad Fauzi Hassan, Nur Sakiinah Ab Aziz \\ Faculty of Islamic Contemporary Studies (FKI), Sultan Zainal Abidin University, (UniSZA), \\ 21300, Terengganu, MALAYSIA. \\ Email: mfathy@unisza.edu.my
}

\begin{abstract}
The Qur'an, as a sacred divine text, was guaranteed integrity from distortion in the composition of its letters, words, sentences, and verses, and this integrity is what is called in the religious terminology: (preservation).The Qur'an is preserved by divine preservation, and this preservation has a well-known basic form: preservation of the hearts, which is a metaphor for the preservation of Muslims of the Qur'an in their hearts by receiving it first from the Prophet PBUH, then from his companions, then to those who followed them. To this day, each of them performs it in the manner that he received from his predecessor, which is known as the receipt, but this receipt in the Prophet's era specifically, needs scientific examination that proves its authenticity in the integrity of the Holy Qur'an from all forms of distortion through the ages that followed. Because it was the era in which the process of receipt began. It is done through exposure to what it is and its evidence, and how it was the cornerstone of the steadfastness of the verses of the Noble Qur'an in front of the currents of direct or indirect change throughout Islamic history. This is the problem that the researcher will try to address in this research through a methodology that relies on extrapolation and tracking of the multiple and accurate images of this reception in the Prophet's era, highlighting its impact on preserving the Qur'anic process after that from any distortion. The researcher has reached several conclusions; One of the most important of them is: The receipt of the Qur'anic verses in the Prophet's era ensured the integrity of the Qur'an text from all forms of self-distortion or deviation after that, and it was a major focus of confidence in the Qur'anic text in terms of reassurance of its integrity, through specific and precise criteria that made it a wall against all attempts to distort or challenge it, for this and others, the researcher advises the need to address this issue from all its aspects, as it relates to the noble book from which all Islamic legal sciences emerge. The integrity of the text is, in fact, the integrity of what is branched from it.
\end{abstract}

Keywords: Impact, Receipt, Prophetic Era, Memorization, The Qur'an, Distortion.

\section{Introduction}

The Qur'an is the last of the divine books that were revealed through revelation to earth from God Almighty upon Muhammad, peace, and blessings be upon him, through Gabriel, peace 
be upon him, and its revelation was a sporadic revelation over twenty-three years. This revelation was by the receipt verbally, for Gabriel, peace be upon him, used to recite verses of The Qur'an which was revealed verbally before the Prophet, may God's prayers and peace be upon him, and at the same time the Prophet, may God's prayers and peace be upon him, used to hear it from him and then repeat it in front of Gabriel, peace be upon him. Then, when the revelation ended, the Prophet, peace, and blessings be upon him, conveyed those revealed verses to His companions, especially the reciters from among them, in the manner that he received from Gabriel, peace be upon him, then he sends these reciters and they inform it to other tribes and regions with accuracy and investigation. This was the practical picture of transferring the Qur'an by the successive reception from heaven to earth, then from the Prophet, may God's prayers and peace be upon him, to his companions, may God be pleased with them. Then from the Companions to those after them, and so on successively, every narrator of the Holy Qur'an relies on narration before him across the timeline to this day, and this method of transferring the Holy Qur'an is what is called receiving a chain of transmission, as it is the means mainly for the safety of the Qur'an text from the self-distortion of the narrated texts because of the succession of times and people, as well as it has the credit for its safety from external distortion that is due to the good intent of his followers or the bad intent of his enemies.

\section{Linguistic Concepts}

For us to understand the topic in all its aspects, we first come to the definition of some of the main terms mentioned in the research as a necessary input to talk about it, which are as follows:

Impact: "The impact of a thing is the occurrence of evidence of its existence" (Al-Asfahani, 2003, 1/19), and from it, the Almighty's saying: "Indeed, it is We who bring the dead to life and record what they have put forth and what they left behind ..." (12), (Yāsīn, 36: 12) it means here the sense of the great impact of receiving the Holy Qur'an with the chain of transmission related to its safety from any distortion.

Receipt: meaning receiving and indoctrination, "the man speaks and reads, that is, he speaks, and I received speech from him" (Al-Farahidi, 2016), and its meaning here is how the Noble Qur'an was transferred orally.

The Prophet's Era: It is the revivalism period of the Prophet Muhammad, may God bless him and grant him peace.

Conservation: It is "a strong and controlled awareness of something so that it is not lost nor slipped away" (Jabal, 2010), and it is here in the sense of preserving the Qur'an and preserving it from any change.

The Qur'an: It is "the miraculous word of God, revealed to the heart of Muhammad, may God's prayers and peace be upon him, worshiped with his recitation, written between the two bookends, transmitted to us frequently, challenged by the shortest surah of it" (Souayyid, 2019).

Distortion: is "adjust and inclined to a letter or aspect (And whoever turns his back upon that day to them, except (in case) of turning off (i.e., turning off "e.g., the road" as a stratagem or to regroup) to fight ...)) (Al-Qur'an, Al-Anfal, 8: 16). Displacing and distorting words of their right places is a tendency to change the meaning, just as by changing the pronunciation. (While a party of them used to hear the words of Allah and then distort it [i.e., the Torah] after they had understood it ...) (Al-Qur'an, Al-Baqarah, 2: 75) " (Jabal, 2010), and here he 
means any alteration or change that violates the integrity of the Qur'an text, whether intentionally or unintentionally.

\section{The Stages of Reception in the Prophet's era, and the Extent of Precision in each of them}

1. The initiation phase: reception is the conjugate of the Qur'anic revelation. Revelation and the reception are mentioned in conjunction with each other. Meaning that it is known a priori that when God Almighty used to allow a certain amount of the Qur'an to descend at a certain time during the revivalism of the Prophet, may God's prayers and peace be upon him, Gabriel, peace be upon him, is sent directly to the Prophet, may God bless him and grant him peace, and the Qur'an told about that in more in more than one place in it, and from it the Almighty's saying: "'Whoever is an enemy to Gabriel - it is [none but] he who has brought it [i.e., the Qur'ān] down upon your heart, [O Muhammad], by permission of Allah, ..." (Qur'an, AlBaqarah, 2: 97), then; This revelation is devoid of any doubt or defect, as it is from the one who said it, and $\mathrm{He}$ is God Almighty, He revealed it through the Revelation Amin who is entrusted in that sacred mission and that is Gabriel, peace be upon him, and who has been described in the Qur'an as very strong and bitter, the Almighty said: One of valiant powers has taught him * One of soundness (Qur'an, An-Najm, 53: 5-6), and he also described it with the following descriptions: "[That] indeed, it [i.e., the Qur'ān] is a word [conveyed by] a noble messenger [i.e., Gabriel] * [Who is] possessed of power and with the Owner of the Throne, secure [in position] * Obeyed there, (and) devoted).

2. The phase of receiving the Messenger, may God's prayers and peace be upon him, from Gabriel, peace be upon him: When Gabriel was sent down to the Prophet, may God's prayers and peace be upon him at some point in time, this revelation was carried out in more than one form, all of which were mentioned in the Qur'an and the Prophet's hadith. The Qur'an for example, reported a form of revelation, which is that Gabriel, peace be upon him, comes to the Prophet, peace and blessings be upon him, in his true angelic form, as in the words of God Almighty: "And he certainly saw him in another descent" (Qur'an, An-Najm, 53: 13), as well as a verse: "And he has already seen him [i.e., Gabriel] in the clear horizon." (Al-Qur'an, At-Takwir, 81: 23). The hadith also reported about two other forms of this encounter, namely: a voice which resembles the sound of a ringing bell, and also the representation of Gabriel, peace be upon him, in the form of human being. As for the sound of a ringing bell, it was mentioned in the hadith on the authority of Aisha, may God be pleased with her: "Al-Harith bin Hisham, may God be pleased with him, asked the Prophet, may God's prayers and peace be upon him, and said: "How does the divine inspiration come to you?" (Al-Bukhari, 2002, 1/ 6) He replied, "In all these ways: The Angel sometimes comes to me with a voice which resembles the sound of a ringing bell (Salsalla), and when this state abandons me, I remember what the Angel has said, and this type of Divine Inspiration is the hardest on me; and sometimes the Angel comes to me in the shape of a man and talks to me, and I understand and remember what he says.", and (Salsalla) is: " iron sound if moved, Abu Suleiman Khattabi said it is -and God knows- a continuous voice he hears but not sure of it when first heard until he understands it and quickly grasps it and fully realize it, that's why he said "and this type of Divine Inspiration is the hardest on me" (Al-Baghawi, 1983, 13/322), As for Gabriel, peace be upon him, in the form of human being, it is as in the hadith: " ... and sometimes the Angel comes to me in the shape of a man and talks to me, and I understand and remember what he says. (Al-Bukhari, 2002, 1/6) "These previous images give us a true visualization of the external image of revelation to the viewer. As for the exact method of the prophet taking 
revelation from Gabriel, it falls under the prophetic receptivity to the Qur'an and which is the first base on receptivity that we are about to talk about. This method has two closely guaranteeing forms for the safety of transfer between the recipient and the one receiving from. The first of them is consistent in all the times of revelation, and its method is through Gabriel, peace be upon him, reciting verses before the Prophet, may God's prayers and peace be upon him, and the Prophet, peace, and blessings of God be upon him, hears them from him, then he reads them before Gabriel, peace be upon him again, and this form that we knew was inferred from his saying: "... And, [O Muhammad], do not hasten with [recitation of] the Qur'ān before its revelation is completed to you, and say, "My Lord, increase me in knowledge." (Qur'an, Taha, 20: 114), and says: "Move not your tongue with it, [O Muhammad], to hasten with it [i.e., recitation of the Qur'ān]. (Al-Qur'an, Al-Qiyamah 75: 1619). The hadith that is narrated by Saeed bin Jabir on the authority of Ibn Abbas, may God be pleased with them both, Concerning the saying of Allah, the Mighty and Sublime:: "Move not your tongue with it, [O Muhammad], to hasten with it [i.e., recitation of the Qur'ān].," - "The Prophet (解) used to suffer a great deal of hardship when the Revelation came to him, and he used to move his lips. Allah said: Move not your tongue concerning to make haste therewith. It is for Us to collect it and to give you the ability to recite it." He said: "(This means) He will gather it in your heart, then you will recite it," And when We have recited it to you, then follow the recitation. He said: "So listen to it and remain silent. So when Jibril came to him, the Messenger of Allah (政) listened, and when he left, he would recite it as he had taught him" (Al-Bukhari, 2002, 1/ 8).

The second form was in Ramadan when a review is made for all the above mentioned. In the Hadith, Abu Huraira said that the Qur'an was gone over* to the Prophet once annually, but that this was done twice in the year in which he died. He used to engage in private devotions in the mosque for ten nights every year, but he did this during twenty nights in the year in which he died (Al-Bukhari, 2002, 8/ 287- 288).

So; These two precise forms are the safety valve for matching the Qur'an text from Gabriel, peace be upon him, in the words of the Prophet, may God's prayers and peace be upon him, and it has been evident to us from the Qur'anic verses and previous prophetic hadiths how accurate the Prophet, may God's prayers and peace be upon him, was keen on every letter Gabriel, peace be upon him, recited. It shows us the extent of the prophetic suffering in enduring this heavy trust, which was evident in his haste in repeating what Gabriel, peace be upon him, recites at the beginning, so the verses of the two aforementioned surahs of Taha and Al-Qiyama were revealed reassuring his heart, may God bless him and grant him peace, that he does not have to bother with the self-preservation of the Qur'an. Rather, God Almighty has ensured its preservation and collection, so there is no need to hurry in repeating for fear of escaping some of it or forgetting it.

Hence, there is an important conclusion that must be proven here, which is that there was no room for the Prophet, may God's prayers and peace be upon him, to take the Qur'an in writing from Gabriel, peace be upon him, as it happened with the prophets before him as Moses, peace be upon him "And We wrote for him on the tablets [something] of all things instruction and explanation for all things..." (The Qur'an, Al-A'raf 7: 145). Indeed, his reception of the Holy Qur'an, may God's prayers and peace be upon him, was verbal because the Prophet, may God's prayers and peace be upon him, was illiterate and did not know writing. He was the only human recipient of the Holy Qur'an, and he was sent in a nation the majority of it were illiterates, so how the revelation was transferred between the Prophets, may God's 
prayers and peace be upon him and his nation, is through memorization by heart, which is known as rote memorization. As for writing during his era, it was a matter of textual documentation, and it was reserved for the revelation writers, and their number was very few. Hence, the Prophet, may God's prayers and peace be upon him, was a guarantor of the integrity of the Qur'an text itself when he communicated it verbally to his companions, and he did not take this Qur'an from a specific book, which allows skeptics because of the possibility that it might be a transmission of the Qur'an from other books before it.

3. The phase of the Companions receiving the Qur'an from the Prophet, may God's prayers and peace be upon him: This phase is the most important phases of receiving the chain of narration, as it is the stage of pure human encounter, and its importance is since it has established the way the Qur'an will subsequently be transferred in form and content through the ages. The form is for the Prophet, may God's prayers and peace be upon him, and the Companions read and listen, in many cases such as prayer, sermon, and others, or for the Companions to recite, may God be pleased with them, and the Prophet, may God's prayers and peace be upon him, listen, and both are the same way that was between Gabriel, peace be upon him, and the Prophet, peace, and blessings be upon him. The content is the precise method for reciting this Qur'an and pronouncing it perfectly that it was revealed with no change or alteration, rather, the striving to ensure that this recitation is completely identical to what it was revealed to it, and the order came so explicitly after he was told that the Qur'an is intoned in itself "...And We have spaced it distinctly." (Al-Qur'an, Al-Furqan, 32). This means it has a specific method of reciting, for it includes rules like Ghunna, Madd, etc. Therefore, its reader must follow that method when reciting it, just as the verse commanded "...and recite the Qur'ān with measured recitation" Al-Muzammil (4: 73). Abu al-Qasim al-Hudhali - who is the oldest to mention this quote - in explaining the meaning of the measured recitation on the authority of Ali bin Abi Talib, may God be pleased with him: "It is the intonation of the letters and the knowledge of the of stopping" (Al-Huzali, 2008, 377). The command to recite the Qur'an in a measured recitation is obligatory, to ensure that it reaches the believers as it is so that they benefit from it in the manner that He Mighty God wanted it to be. This is what the Prophet, may God's prayers and peace be upon him, and his companions were keen on, in compliance with the divine command in His words: "And [it is] a Qur'ān which We have separated [by intervals] that you might recite it to the people over a prolonged period..." (The Qur'an. Al-Israa. 106). Indeed, God has commanded him to recite to some of his companions, like Ubayy b. Kā'b, for Ubayy b. Kā'b to learn from the recitation of the Prophet peace be upon him. Anas reported God's messenger as saying to Ubayy b. Kā'b, "God has commanded me to recite the Qur'ān to you." He asked, "Did God mention me to you by name?" and when he was told that He had, he said, "Have I been mentioned in the presence of the Lord of the universe?" On being told that he had, tears fell from his eyes. In a version, he said God had commanded him to recite to him "Those who disbelieve were not ..." (Qur'ān, 98). He asked if He had mentioned him by name, and when he was told that He had, he wept" (Al-Bukhari, 2002 , 8/256) And this matter was one of the matters that he, peace and blessings be upon him, used to be very keen on. In the Hadith on the authority of Anas bin Malik, may God be pleased with him, he says: "Abu Talha came one day, and he saw Prophet, may God bless him and grant him peace standing, teaching Qur'an to the people of Siffa while fastening his stomach with stone from hunger" (Alasbhany 1074, 1/342). His hunger, peace, and blessings are upon him, did not prevent him from teaching the Qur'an to his companions. 
Likewise, all of the Companions, may God be pleased with them, were keen to listen directly to the recitation of the Prophet, may God's prayers and peace be upon him. Some of them heard his recitation in the obligatory prayer, as the narration of Al-Baraa bin Azeb clarifies,

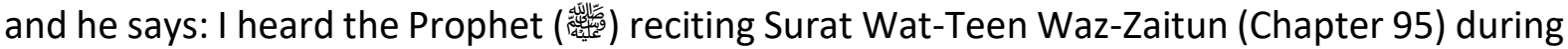
the 'Isha' prayer. I have never heard anyone reciting it in a more beautiful voice than his." (Muslim, 2002, 1/ 337). Some heard him in the sermon on the pulpit. Umm Hisham (RA) daughter of Haritha said: I learned Surat Qaf (Chapter 50) from no other source than the

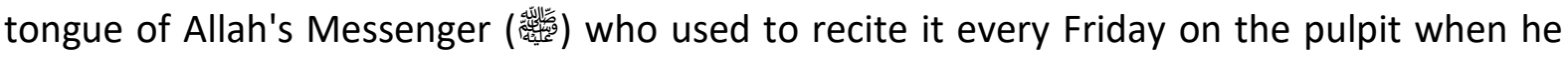
delivered the Khutbah (sermon) to the people." Muslim, 2002, 2/ 595), Then the Prophet's recitation spread in its recited way and its specific performance among the Companions. It became a habit for them on their tongues that they do not deviate from when they recite the Holy Qur'an, following the method of the Prophet in the recitation. It is as well to obey the order of reciting in the previous verse, and then to strictly comply with the Prophet's exhortation to be accurate in receiving. In the hadith on the authority of Abdullah bin Masoud, he said: "I heard the Prophet, may God's prayers and peace be upon him, say: "May Allah cause his face to shine, the man who hears a Hadith from us and conveys it, for perhaps the one to whom it is conveyed may remember it better than the one who (first) hears it." "( Ibn Hibban،, 1993, 69). There is as well another Hadith in the same context, Jobair ibn Mot'im may Allah be pleased with him from the Prophet peace be upon him, he said May Allah cause his face to shine, the man who hears my Hadith, memorize it and perform it as he heard it..." (Al-Bazaar, 2009, 3416). We notice in the two aforementioned hadiths that two sentences were mentioned: (and conveys it as he heard it), and (and perform it as he heard it), and this shows the prophetic concern for accuracy and honesty in transmission without change or alteration. Those two phrases were mention in Hadith, and the same meaning is a fortiori be mentioned in Qur'an.

The teaching of the Noble Qur'an has become a common and frequent matter among the Companions, may God be pleased with them. The witness from them informs the absent of them of what was reported of Qur'an from the Messenger of God, may God bless him and grant him peace. Anas, may God be pleased with him, describes this situation and says: "They would sit after Fajr prayer in circles reciting Qur'an and learning what is obligatory and what is Sunnah" (Ibn Hajar,2000, 12/ 711).

There are ample shreds of evidence for the accuracy of the Companions and their keenness on it and for receiving it in the manner that they took from the Prophet, may God bless him and grant him peace, without an increase or decrease. In addition to their vigilance against any alteration or change in its text or its performance. In the hadith narrated by Umar ibn alKhattab, may God be pleased with him, he says: "I heard Hisham bin Hakim reciting Surat-alFurqan during the lifetime of Allah's Messenger (解), I listened to his recitation and noticed that he was reciting in a way that Allah's Messenger (然) had not taught me. I was about to jump over him while He was still in prayer, but I waited patiently and when he finished his prayer, I put my sheet round his neck (and pulled him) and said, "Who has taught you this Sura which I have heard you reciting?" Hisham said, "Allah's Messenger (定) taught it to me." I said, "You are telling a lie, for he taught it to me in a way different from the way you have recited it!" Then I started leading (dragged) him to Allah's Messenger (鹳) and said (to the Prophet), " I have heard this man reciting Surat-al- Furqan in a way that you have not taught

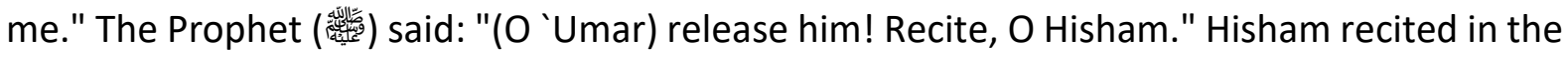


way I heard him reciting. Allah's Messenger (政) said, "It was revealed like this." Then Allah's Messenger (触) said, "Recite, O 'Umar!" I recited in the way he had taught me, whereupon he said, "It was revealed like this," and added, "The Qur'an has been revealed to be recited in seven different ways, so recite of it whichever is easy for you" (Muslim, 2002, 1/ 186- 188). This is an example of their jealousy and their attention on the Qur'an among each other. This attention extended after the death of the Prophet, may God bless him and grant him peace, and there are shreds of evidence for it. We mention this narration from Musa bin Yazid al-Kendi, he said: Ibn Masood was teaching Qur'an to a man, who recited: "Zakāh expenditures are only for the poor and for the needy..." He recited "الفقراء" (needy) without adding Madd, then Ibn Masood said: "This is not how the prophet taught me to recite it" So

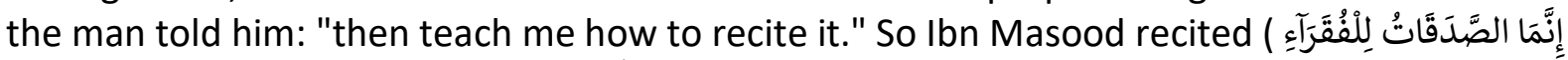

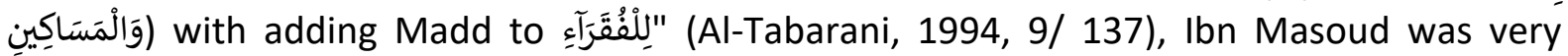
accurate to the extent that he stopped the man from reciting because he didn't add Madd, although the meaning did not change by this wrong performance by the man by reading it adding Madd, i.e.: he did not extend it.

Every difference in the performance of Qur'anic words has an impact on interpretation, for it is considered a difference in meaning. The different Qur'anic readings all do not contradict each other, but rather they are consistent with each other. Scholars and researchers have paid great attention to Qur'anic readings (Abdelgelil, 2020); this is because the Noble Qur'an and the ten Qur'anic readings include everything whether ancient, modern, contemporary and non-contemporary, from family and life affairs (Abdelgelil, 2018). Interest in the science of readings has become noticeable in literature, universities, and scientific departments (Abdelgelil, 2019).

\section{Conclusion}

After we discussed the topic of receipt in the Prophet's era and its effect on establishing the integrity of the Qur'an text, several results emerged to us, the most prominent of which are: 1. That the Qur'an is preserved by the pure divine preservation. God alone may guarantee it as stated in the verse. Thus, receiving is the physical and visual image of the divine guarantee for preserving the Holy Qur'an and its integrity from any distortion or alteration, in which the Prophet's era was the first building block.

2. The Prophet, may God's prayers and peace be upon him, was keen and accurate in conveying the Noble Qur'an to his companions in the same manner that he received from Gabriel, peace be upon him, and urged to do the same.

3. The Companions, may God be pleased with them, were keen to receive the Noble Qur'an from the mouth of the Prophet, may God's prayers and peace be upon him, and were extremely accurate in conveying it with the same text and the same performance, in addition to their attention and panic when noticing any flaw that is different from what they have received of the Qur'an from the Prophet. They would hurry to the Prophet Peace be upon him to clarify and to detail to them what is correct and right.

4. That the honest and accurate reception in the Prophet's era was the solid foundation that preserved the Qur'anic process after that from any change or alteration. This basis was the safety valve against any intentional or unintended distortion.

We recommend that researchers follow the path of Qur'anic reception throughout Islamic history. To show the extent of the accuracy of the nation in communicating the trust of the Qur'an with the accuracy that it preserved from alteration and change. 


\section{References}

Al-Quraan Al-Karim.

Abdelgelil, M. F. M. (2020). Grammarians' Critique of Qur'anic Qira'at. International Journal of Academic Research in Business and Social Sciences, 10(11), 1225-1231.

Abdelgelil, M. F. M. (2020). Solving the Quranic Issues with Quranic Qira'at, International Journal of Academic Research in Business and Social Sciences, 10(12), 36-42.

Abdelgelil, M. F. M., Al-Janayni, M. U., Baru, R., Hamzah, M. S., Razali, M. A. T. M., \& Ismail, F. Z. (2018). Tawjih Al-Qira'at Based on Inscription, Language, and Unusual Modes of Recitation According to Ibn Zanjalah. International Journal of Academic Research in Business and Social Sciences, 8(10), 362-370.

Abdelgelil, M. F. M., Daud, N. B., Omar, N. B., Ismail, F. Z. B., \& Wahab, A. H. B. A. (2018). Taujeeh Al-Qira'at Using Qur'an, Hadith and Poetry according to Ibn Zanjalah. International Journal of Academic Research in Business and Social Sciences, 8(10), 371-379.

Abdelgelil, M. F. M., Musolin, M. H., Serour, R. O. H., Abdullah, M. S., \& Noor, M. N. M. (2018). Law and Moral Values in the Holy Quran. International Journal of Academic Research in Business and Social Sciences, 8(11), 445-451.

Abdelgelil, M. F. M., Hassan, A., Yusof, N. H., Idris, M. F. H., Hasan, A. F., \& Ramadan, A. A. (2020). Defending the Quran in the Study of Tawjeeh Al-Qira'at, International Journal of Management, 11(10), pp. 101-104.

Abdelgelil, M. F. M., Razali, M. A., Hassan, A., Hasan, A. F., Idris, M. F. H., \& Masoud, A. S. (2020). Quranic Inimitability in Quranic Qiraat, International Journal of Management, 11(10), pp. 117-121.

Alasbhany, A. A. (1974). Hilyah Alaolya' Wa Tabakat Alasfya'. Cairo: Dar Als'adah.

Al-Asfahani, A. M. (2003). Al Mufradat Fi Kharib Al-Quraan. Cairo: Al-Maktabah AlTawfiqhoyyah.

Al-Baghawi, A, M. (1983). Sharh al sunnah. Investigation: Shuaib al-arnaut. Dimashq: almaktab al-islami.

Al-Bazaar, A. A. (2009). Al-Bahr Al-Zarkhar Fi Musnad Al-Bazar. Al-Madinah Al-Munawwarah: Maktabah Al-Ulum Wa Al-Hikam.

Al-Bukhari, M. I. (2002). Sahih Al-Bukhari. Investigation: Muhammad Zuhir. Cairo: Dar Tauq Al-Najat.

Al-Farahidi, A. A. (N. D). Kitab Al-Ain. Investigation: Mahdi Al-Makhzumi And Ibrahim AlSamirra'i. Bairut: Dar And Maktabah Al-Hilal.

Al-Huzali, A, Q. (2008). Kitab Al-Waqf Wa Al-Ibtida' Fi Kitab Allah. Investigation: Ammar Amin Al-Duddu. Sharia And Law Journal: Vol 34, Pp 345- 415.

Al-Tabarani, S. A. (1994). Al-Mujam Al-Kabir. Investigation: Hamdi Ibn Abdul Majid. Cairo: Maktabah Ibn Taimiah.

Ibn Hajar, A. A. (2000). Al-Matalib Al-Aliyah Bizawa'd Al-Masanid Al-Thamaniah. Al-Riyad: Dar Al-Asimah And Dar Al-Gaith.

Ibn Hibban, M. B. (1993). Sahih Ibn Hibban Bitartib Ibn Blban. Investigation: Syo'aib Alarnaut. Bairut: Ma'ssasah Al-Risalah.

Jabal, M. H. (2010). Al-Mu'jam Al-Ishtiqaqi Al-Mua'ssal Li Alfaz Al-Quran. Cairo: Maktabah AlAadab.

Muslim, M. A. (2002). Sahih Muslim. Investigation: Muhammad Fouad Abdul Baky. Bairut: Dar Ihya' Al-Turath Al-Araby. 
INTERNATIONAL JOURNAL OF ACADEMIC RESEARCH IN BUSINESS AND SOCIAL SCIENCES

Vol. 11, No. 9, 2021, E-ISSN: 2222-6990 (c) 2021 HRMARS

Souayyid, A. R. (2019). Al-Tajwid Al Musawwar Bi Allughah Al-Malaywiyyah. Turki: Dar AlGhuthani. 